\title{
PERCEIVED RISK, INTENTION TO USE AND ACTUAL USE OF MOBILE BANKING IN MALAYSIA: AN EXTENDED DECOMPOSED THEORY OF PLANNED BEHAVIOR
}

\author{
Murat Mahad', Shahimi Mohtar ${ }^{2}$ \\ ${ }^{1}$ College of Business, Universiti Utara Malaysia, 00601 Sintok, Kedah, \\ Malaysia \\ ${ }^{2}$ Technology, Operation and Logistics Management, College of Business, \\ Universiti Utara Malaysia, 00601 Sintok, Kedah, Malaysia \\ muratmahad74@gmail.com; shahimi@uum.edu.my
}

\begin{abstract}
Mobile banking refers to the use of smart phones or other mobile devices to perform tasks online banking from your home computer, such as monitoring the account balances, transfer of funds between accounts, pay bills and prepaid top-up. Mobile banking is a new strategy for the bank to enhance their latest technology in a new dynamic marketing environment. The low penetration of mobile banking in Malaysia, especially in terms of adoption patterns is becoming the research interest, especially when compared to the total number of cellular telephone subscriptions. Even if mobile banking is relatively new in Malaysia, it is very important for the banks to mitigate this issue and thus can draw more users. The issue of risk in term of security, privacy, financial, Time and performance is the five important dimensions in risk factor that may affect the user's intention to adopt the mobile banking services.
\end{abstract}

Keywords: Mobile Banking, Decomposed Theory of Planned Behavior, Perceived Risk JEL Classification: O30 